\title{
The Effect of Matlab Software Mastery on The Students' Learning Motivation of Linier Equation and Matrix Materials
}

\author{
Nur Yuliany ${ }^{1)}$, Suharti $^{2)}$, A. Sriyanti ${ }^{3)}$ \\ ${ }^{123}$ Fakultas Tarbiyah dan Keguruan UIN Alauddin Makassar

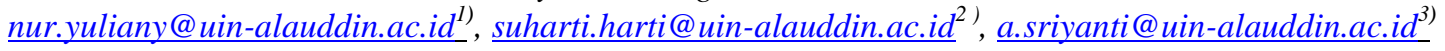

\begin{abstract}
The study aimed to determine the effect of motivation on the learning outcomes of linear equation and matrix materials by using Matlab software. This study was an ex-post facto quantitative research. The sampling technique used is simple random sampling. The descriptive test results showed that the average student learning motivation score was 61.46 which means that the learning motivation score was in the moderate category in general, while the mean value for the linear equation and matrix materials of the students learning outcomes was 69.29 which meant that the mathematics learning outcomes were in the medium category, while the inferential test results by using the results of regression test analysis proved that the regression equation obtained was $Y=6.557+1.021 X$. From the results of the significant test, it was obtained the significant value as many as 0.389 , the result from the significant value $>0.05(0.389>0.05)$, so that $\mathrm{H} 0$ was accepted. It could be inferred that there was significant effect on the learning motivation by using Matlab software toward the students' learning outcomes of linear equations and matrix materials.
\end{abstract}

Keywords: Matlab Software, Learning Motivation, Linear Equation, and Matrix

\section{Introduction}

The education needed by humans is a necessity that must be fulfilled throughout the life. Without the education, it is impossible for the human beings to develop their ideals to progress, be happy, and prosper based on the view of human's life (Ihsan, 2010). It shows the importance of education for humans that is able to lead them into a good and more advanced future so that the education role is very necessary in human's life because it is needed all the time. Therefore, the education process must be fulfilled by every human being. Through the education, it is expected that the human can become an educated and developing person in the community. Along with the development of education and science, the learning process gets many changes, both the changes in the curriculum and the changes in the implementation of various learning facilities, as well as the learning media becoming more sophisticated that facilitate the convenience in the learning and teaching processes. The sophistication of the learning media must be followed by mastery in using the media either as the teachers or as the students.

The technological advances that have penetrated to the educational world contribute much to the learning processes. The easiness in accessing the information related to the learning proves it. So, learning in this era not only focuses on using the handbook in the school but also on using other book resource forms such e-book, e-journal, article, and so forth. This technology development should be utilized properly especially in the educational world. It is the time that the educators should move on from their old habit of only focusing on the use whiteboard when teaching. The electronic media should be utilized properly in the learning processes that can result a new atmosphere in the classroom.

The computer is a sophisticated device created from the advanced technology. Various applications can be used by using this device. Moreover, the calculation processes can be easily done by using it, both in processing and displaying the data. The observation in the learning environment can be conducted easily by using the computer (Ibrahim, 2009). The convenience in using the computer's applications is expected can be utilized in the educational world especially in studying mathematics such as algebraic material, calculus, numerical method, matrices, and so forth. 
Abdurrahman (2003) states that mathematics functions to express the relationship in the form of symbolic language, and theoretically makes it easy to think logically. As a symbolic language, mathematics can give possibility to everyone to express his/her ideas that will be communicated in a symbolic form. The mathematical ability brings a person to have reasonable ability, both deductively and inductively.

Mathematics is one of the subjects that closely related to the information system, in which a teacher should be more careful about it. As a matter of fact, the students have different mastery levels on the materials given. Considering the learning processes conducted in an educational institution has short time duration, the teacher or the lecturer is expected to use laptop, LCD projector, or other media to save the time so that the learning objectives in every meeting can be achieved even in quite short time duration, and further discussion about the roles of mathematics in the information technology development can achieved as well. The use of computer technology in the learning processes is actually a policy that should be prepared and implemented. In addition, the learning materials cannot be understood only through the analysis process and algebra but also it is strengthened with the help of computer program application in order to improve the students' achievement in mastering the materials. Even more important is that through the use of computer, it is expected that the students are more motivated to improve and develop their abilities, and practice independently with easier, regular, and not boring ways (Suhandri, 2016).

There are various kinds of application programs or software that can be used in the learning processes that can make easier in answering complex tests both in drawing the chart and presenting it in the table. The main things are the knowledge, insight, and skill of the teacher in using those various kinds of application programs as well as able to select the appropriate application to support the learning with the certain topic, in this case the linier equations and matrix (Cahyono, 2013). One of the application programs that can be used in the learning process of linier equations and matrix is Matrix Laboratory (Matlab). Matlab is an abbreviation of Matrix Laboratory that was firstly introduced by University of New Mexico and University of Stanford in 1970. The application program can be used to increase the speed and the significance for various calculations in matrix materials so that the time needed to work on it will be more efficient and the result obtained will be more efficient than the calculation done manually, so it is expected that it can increase the students' motivation in learning mathematics especially in answering the tests. Motivation is the external and internal processes of a human that causes the enthusiasm and persistence in doing certain activities (Winardi, 2002). According to Pebruanti \& Munadi (2015), motivation is the energy change occurring in oneself signed by the affective and reactive response to gain the goal. Sankey (2005) stated that the trend towards the use of multimedia learning technology as the basis of teaching has increased.

The indicators of learning motivation are: a) the students are diligent in doing their homework, b) the students are diligent in challenging the difficulties or they never give up when facing difficulties, c) the students are interested in various kinds of learning materials, d) the students like doing their homework alone more, e) the students are bored in doing the routine tasks, and f) the students are able to maintain their opinions. Motivation can be interpreted as a power owned by a person that causes the desire and willingness to carry out an activity. The willingness can come from both inside the self or intrinsic motivation and outside or extrinsic motivation. How much the level of motivation inside the self will largely determined by the behavior quality shown, either in the learning processes, in the working processes, or other cycles (Sardirman, 2005). 
The research findings conducted by Kartika (2014) concluded that using Matlab software could increase the mathematical communication ability compared with the direct learning. It can be seen through the high category of the mathematical communication ability. Another research also conducted by MS \& Baysha (2018), they stated that there was an effect of Matlab on the students' learning outcomes in Mathematics subject of the seventh year students at the State Senior High School 5 Kopang in Lombok regency of academic year 2017/2018.

Based on the description above, it is presumed that there is an effect of the students' learning motivation and positive attitude on learning linier equations and matrix through the use of Matlab application program. That is the underlying reason the researcher to conduct the study about the effect of students' learning motivation on the mastery of Matlab software use.

\section{Method}

The study used quantitative approach of ex-post facto research design. Ex-post facto is an empirical research design conducted systematically. The researcher does not control the independent variables due to the existed manifestation or the un-manipulated variables inherently (Kerlinger, 1993). Sample Random Sampling was used as the research sampling technique. Sample is the number of members selected/taken from a population (Tiro, 2011).

According to Sugiyono (2010), the instrument in quantitative research can be in the forms of test, interview, observation, an questionnaire. In this study, the instrument used to find out the students' learning motivation was the questionnaire. In addition, the instrument used to find out the learning outcome levels was the score documentation in the form of essay taken from the lecturer of linear algebra subject.

The descriptive statistic was used to analyze the data from the research variables, while the inferential statistic was used to analyze the effect of learning motivation on the learning outcomes of linear equations and matrix materials through the use of Matlab application program.

\section{Result}

Based on the categorization criteria, it was obtained the frequency distribution of the learning motivation score as presented in the following table:

Table 1. The Score Distribution of Learning Motivation

\begin{tabular}{ccccc}
\hline No & Score & Frequency & Percentage (\%) & Category \\
\hline 1 & $20 \leq \mathrm{MB}<45$ & 0 & 0 & Very Low \\
2 & $45 \leq \mathrm{MB}<55$ & 0 & 0 & Low \\
3 & $55 \leq \mathrm{MB}<65$ & 21 & 75 & Medium \\
4 & $65 \leq \mathrm{MB}<75$ & 7 & 25 & High \\
5 & $75 \leq \mathrm{MB} \leq 80$ & 0 & 0 & Very High \\
\hline \multicolumn{7}{c}{ Total Score } & 28 & 100 & \\
\hline Mean & Std. Deviation & Variance & Minimum & Maximum \\
\hline 61.46 & 4.096 & 16.777 & 54 & 69 \\
\hline
\end{tabular}

Data Source: Primer, 2018.

The mean score of the learning motivation showed in the table above is 61.46 which means that generally the students' learning motivation score refers to medium category. None of students got very low and low category of learning motivation. Based on the data, it can be concluded that the 
students' motivation to learn linear equations and matrix is on the medium category which indicates that the students are ambitious, work hard, compete, and diligently try in learning participation.

Data berikut menunjukkan nilai hasil belajar mahasiswa dalam materi persamaan linear dan matriks dengan penerapan software matlab, data ini merupakan dokumen hasil mid semester dari mata kuliah aljabar linear.

Tabel 2. Distribusi Nilai Hasil Belajar

\begin{tabular}{ccccc}
\hline No & Score & Frequency & Percentage (\%) & Category \\
\hline 1 & $0 \leq$ THB $<40$ & 0 & 0 & Very Low \\
2 & $40 \leq$ THB $<55$ & 0 & 0 & Low \\
3 & $55 \leq$ THB $<75$ & 20 & 71.43 & Medium \\
4 & $75 \leq$ THB $<90$ & 8 & 28.57 & High \\
5 & $90 \leq$ THB $\leq 100$ & 0 & 0 & Very High \\
\hline & Total Score & 28 & 100 & \\
\hline Mean & Std. Deviation & Variance & Minimum & Maximum \\
\hline 69.29 & 6.699 & 44.877 & 60 & 84 \\
\hline
\end{tabular}

The mean score of the learning outcomes for linear equations and matrix materials is 69.29 which means that it is in the medium category, and none of students got very low, low, and very high category.

The result of the research data in the form of learning motivation and learning outcome scores of linear equations and matrix materials that were firstly tested through normality test and linearity test are as follows:

Table 3. Normality Test

\begin{tabular}{cc}
\hline Variable & p-value (sig) \\
\hline Learning Motivation & 0.180 \\
Learning Outcomes & 0.650 \\
\hline
\end{tabular}

The table shows that the variables of learning motivation and learning outcomes are normally distributed. It can be seen from sig $>0.05$.

Table 4. Linearity Test

\begin{tabular}{ccc}
\hline Correlation & F & p-value (sig) \\
\hline $\mathrm{XY}$ & 0.868 & 0.599 \\
\hline
\end{tabular}

Through the data analysis by using SPSS, it is found the significant value of 0.599 . In this case, it means that the significant value is greater than $\alpha$ or $(0.599>0.05)$. Therefore, it can be concluded that the learning motivation by using Matlab software (X) and the learning outcomes of linear equations and matrix materials $(\mathrm{Y})$ have linear relationship. For details, see in the appendix.

To determine the effect of learning motivation by using Matlab software toward the learning outcomes of linear equations and matrix materials, the study used simple linear regression analysis with the output result as follows: 
Table 5. The Significant Test of Simple Linear Regression Coefficient

\begin{tabular}{ccc}
\hline Model & $\mathbf{R}^{2}$ & p-value (sig) \\
\hline $\mathrm{X}_{1} \mathrm{Y}$ & 0.389 & 0.001 \\
\hline
\end{tabular}

The table above shows that the value of $\mathrm{R} 2$ ( $\mathrm{R}$ Square) is 0.389 or (38.9\%). The value indicates that the contribution percentage of the learning motivation by using Matlab software toward the learning outcomes of linear equations and matrix materials is $38.9 \%$, while the sig value is $<0.05$ $(0.001<0.05)$, therefore, $\mathrm{H} 0$ is rejected. It is inferred that there is significant effect of learning motivation by using Matlab software toward the learning outcomes of linear equations and matrix materials.

The value of simple linear regression coefficient in the appendix shows that the value of the constant coefficient is 6.557 , and the coefficient of independent variable $(\mathrm{X})$ is 1.021 . The result of the simple linear regression equation is as follows:

\section{Discussion}

$$
\mathrm{Y}=6.557+1.021 \mathrm{X}
$$

The result of the descriptive statistic analysis shows that the students learning motivation scores are categorized as medium and high. Overall, the students' mean scores are in the medium range, while the standard deviation of 4.096 indicates that the standard deviation is quite small. The smaller the standard deviation is, the closer the mean score of the learning motivation will be. The learning motivation score of every respondent is closer to the mean score of the learning motivation. It can be seen through the smaller range of the standard deviation

The students' learning outcomes of linear equations and matrix materials have the mean score that indicate to the medium category, while the value of the standard deviation is 6.699. It indicates that the range score of every respondent has a considerable distance with the learning outcome scores. The highest score of the mid-semester is 84 which is categorized as high of $28.57 \%$ from the respondents. The highest ability of the respondent is (71.43\%) which is categorized as medium. It indicates that the ability in completing the test of linear equations and matrix materials is quite good, even the students need to practice more in order to get better scores.

The result of inferential statistic was used to answer the research question hypothesis of this study. Before testing the analysis, the data were tested through the normality and linearity tests. The data of the learning motivation and the learning outcomes of linear equations and matrix materials showed that the data were normal and have linear correlation. Because the data were normally distributed and there is linearity correlation, the data were then analyzed by using simple linear regression to answer the hypothesis of this study.

Hasil penelitian ini diperkuat oleh hasil penelitian Kartika (2014) menyimpulkan bahwa dengan penggunaan software Matlab dapat meningkatkan kemampuan komunikasi matematika dibandingkan dengan pembelajaran langsung, hal ini terlihat dari kemampuan kemunikasi matematika berada pada kategori tinggi. Hasil penelitian Rosalina (2014) memperlihatkan bahwa semakin baik menggunakan software Matlab maka semakin tinggi minat belajar siswa kelas X SMK N 2 Karang Baru, dengan uji hipotesis diperoleh hasil bahwa Fhitung > Ftabel yaitu 42,35 > 3,92 sehingga dapat disimpulkan penggunaan software Matlab berpengaruh signifikan terhadap minat belajar siswa pada materi matriks kelas X SMKN 2 Karang Baru. Hasil penelitian yang dilakukan Arfahmi (2013) dan Islamiyah (2017) menyimpulkan bahwa praktikum Matlab berpengaruh terhadap hasil belajar mata 
kuliah pemrograman komputer basic. Hasil penelitian yang dilakukan Andriani (2017) terdapat pengaruh yang signifikan motivasi belajar dengan penggunaan software Matlab terhadap hasil belajar mahasiswa pada materi persamaan linear dan matriks. Sehingga hal ini semakin memperkuat hasil penelitian ini, bahwa dengan penggunaan software Matlab dapat meningkatkan motivasi belajar mahasiswa dalam belajar persamaan linear dan matriks. Maka variabel motivasi belajar harus menjadi perhatian khusus agar hasil belajar dapat lebih baik. Perlu pemanfaatan teknologi agar pembelajaran lebih menarik dan meningkatkan motivasi mahasiswa dalam belajar.

\section{Conclusion}

Based on the findings and discussion, the conclusions of this study are: the mean score of the students' learning motivation is 61.46 which means that generally it is categorized as medium. The mean score of the students' learning outcomes of linear equations and matrix materials is 69.29 which means that it is also categorized as medium. There is the accurate effect of learning motivation by using Matlab software on the learning outcome results of linear equations and matrix materials. The result of the regression analysis proves that the regression equation is $Y=6.557+1.021 X$. Based on the result of the significant test, it is obtained the significant value of 0.389 with the significant value of $>0.05(0.389>0.05)$, so that $H_{0}$ is accepted. Therefore, it is concluded that there is the significant effect of learning motivation by using Matlab software toward the students' learning outcomes of linear equations and matrix materials.

\section{References}

Abdurrahman, M. (2003). Pendidikan Bagi Anak Berkesulitan Belajar (II). Jakarta: PT. Rineka Cipta.

Andriani, I. (2017). Analisis Penguasaan Software Matematika Matlab pada Materi Persamaan Linear dan Matriks Mahasiswa Jurusan Pendidikan Matematika Universitas Islam Negeri Alauddin Makassar Angkatan 2016/2017. UIN Alauddin Makassar.

Arfahmi. (2013). Model Matematika pada Tingkat Kontribusi Praktikan Matlab terhadap Hasil Belajar Mata Kuliah Pemograman Komputer Basic pada Mahasiswa Jurusan Pendidikan Matematika Tahun Akademik 2012/2013. IAIN Mataram.

Cahyono, B. (2013). Penggunaan Software Matrix Laboratory (Matlab) dalam Pembelajaran Aljabar Linier. Jurnal PHENOMENON, 3(1), 45-62. Retrieved from http://journal.walisongo.ac.id/index.php/Phenomenon/article/view/174/155

Ibrahim, N. (2009). Pengaruh Pembelajaran Berbantuan Komputer terhadap Hasil Belajar (Meta Analisis). Jurnal Pendidikan dan Kebudayaan, 15(1), 108-125.

Ihsan, F. (2010). Dasar-Dasar Kependidikan Komponen MKDK. Jakarta: PT. Rineka Cipta.

Islamiyah, W. (2017). Penggunaan Praktikum Matlab terhadap Hasil Belajar Mata Kuliah Pemrograman Komputer Basic (PKB) Mahasiswa Semester IV Tadris Matematika UIN Mataram tahun akademik 2016/2017. UIN Mataram.

Kartika, H. (2014). Pembelajaran Matematika Berbantuan Software Matlab sebagai Upaya Meningkatkan Kemampuan Komunikasi Matematis dan Minat Belajar Siswa SMA. Jurnal Pendidikan UNSIKA, 2(1), 24-35. Retrieved from https://journal.unsika.ac.id/index.php/judika/article/view/119 
Kerlinger, F. N. (1993). Foundations of Behavioral Research. (L. R. Simatupang, Ed.). Yogyakarta: Gajah Mada University.

MS, A., \& Baysha, M. H. (2018). Pengaruh Media Pembelajaran Matrix Laboratory (Matlab) terhadap Hasil Belajar Siswa. Jurnal Teknologi Pendidikan, 3(2), 10-20. Retrieved from https://www.neliti.com/publications/273090/pengaruh-media-pembelajaran-matrixlaboratory-matlab-terhadap-hasil-belajar-sisw

Pebruanti, L., \& Munadi, S. (2015). Peningkatan Motivasi dan Hasil Belajar pada Mata Pelajaran Pemograman Dasar Menggunakan Modul di SMKN 2 Sumbawa. Jurnal Pendidikan Vokasi, 5(3), 365-376. Retrieved from https://journal.uny.ac.id/index.php/jpv/article/view/6490

Rosalina, D. N. (2014). Pengaruh Software Matlab terhadap Minat Belajar Siswa pada Materi Matriks. STAIN Zawiyah Cot Kala Langsa.

Sankey, M. D. (2005). Multimodal Design and The Neomillennial Learner. A Paper Presented to The OLT 2005 Conference, QUT, Brisbane, 251-259. Retrieved from https://www.researchgate.net/publication/242164285_Multimodal_design_and_the_neomillen ial_learner/link/54935c3c0cf25de74db4f2b0/download

Sardirman, A. M. (2005). Interaksi dan Motivasi Belajar Mengajar. Multimodal Design and The Neomillenial Learner. Jakarta: Grafindo.

Sugiyono. (2010). Metode Penelitian Bisnis. Bandung: Alfabeta.

Suhandri. (2016). Implementasi Program Aplikasi Maple untuk Meningkatkan Prestasi dan Motivasi Belajar Mahasiswa pada Perkuliahan Kalkulus Integral. Suska Journal of Mathematics Education, 2(1), 57-66. Retrieved from https://core.ac.uk/download/pdf/153775709.pdf

Tiro, M. A. (2011). Teknik Pengambilan Sampel. Makassar: Andira Publisher.

Winardi. (2002). Motivasi dan Pemotivasian dalam Manajemen. Jakarta: Raja Grafindo Persada. 